\title{
Anti-Oxidant and Antiinflammatory Effects of Rosa multiflora Root
}

\author{
Geun-Hye Park', Jin-Young Lee ${ }^{2}$, Dong-Hee Kim', Young-Je Cho ${ }^{3}$ and Bong-Jeun An ${ }^{1}$ * \\ ${ }^{1}$ Department of Cosmeceutical Science, Daegu Haany University, Gyeongbuk, 712-715, Korea \\ ${ }^{2}$ Department of Herbal Cosmetic Science, Hoseo University, Chungnam, 336-795, Korea \\ ${ }^{3}$ Department of Food Engineering, Gyungbuk National University, Daegu, 702-701, Korea
}

Received April 5, 2011 /Revised July 20, 2011 /Accepted August 26, 2011

\begin{abstract}
Rosa multiflora thunberg belonging to Rosaceae is widely distributed in East Asia including Korea and Japan, and has been reported to have tormentic acid and rosamultin. To develop a new natural anti-inflammatory agent for cosmetics, we investigated the inhibitory effects of inflammation in Rosa multiflora root ( $R$. multiflora root). The biological activity and anti-inflammatory effects were investigated by water, ethanol, methanol and acetone extracts of $R$. multiflora root. The measurements of polyphenol content from $R$. multiflora root were highest in water and acetone extracts, at $57.48 \pm 0.88 \mathrm{mg} / \mathrm{g}$ and 67.05 $\pm 0.56 \mathrm{mg} / \mathrm{g}$, respectively. The result of DPPH, ABTS and superoxide anion radical scavenging effects showed over $50 \%$ efficacy at $50 \mathrm{\mu g} / \mathrm{ml}$ in ethanol, methanol and acetone extracts. Hyaluronidase inhibition effect showed over $60 \%$ efficacy at $500 \mu \mathrm{g} / \mathrm{ml}$ in ethanol, methanol, and acetone extracts. Nitric oxide radical inhibition effect of $R$. multiflora root ethanol extracts showed over $30 \%$ efficacy at 500 $\mu \mathrm{g} / \mathrm{ml}$. We investigated the effect of $R$. multiflora root extracts on nitric oxide (NO) production of inducible nitric oxide synthase (iNOS) in LPS-induced RAW 264.7 macrophage cells. The result showed that $R$. multiflora root extracts have an inhibitory effect on NO production and iNOS expression and also can be used as an anti-inflammatory agent. These antioxidant and anti-inflammatory effects of $R$. multiflora root show applicant potential application as a functional cosmetic material.
\end{abstract}

Key words : Rosa multiflora root, antioxidant effect, anti-inflammatory, nitric oxide (NO), inducible nitric oxide synthase (iNOS)

\section{서 론}

찔레나무(Rosa multiflora Thunberg)는 장미과(Rosaceae)에 속하고 한의학에서는 석산호(石刪湖)로 불리고 있으며, 열매 는 영실(營實), 또는 색미자(巫薇子)라 하여 약으로 귀하게 쓰인다. 한국, 일본을 비롯한 동아시아지역 야산에 광범위하 게 분포하는 낙엽관목이며, 학명 중의 multiflora는 꽃이 많다 는 의미이다. 열매는 9 10월에 붉게 익어 다음해까지 달려 있으며, 그 뿌리는 청열, 이습, 거풍, 활혈에 효능이 있어 당 뇨병, 관절염, 토혈, 월경불순, 타박상의 치료목적으로 민간 에서 사용되어 왔으며, 성분으로는 triterpenoid인 tormentic acid와 그 배당체인 rosamultin이 보고되어 있다[12]. 찔레 꽃 증류액은 구창, 당뇨병, 심장질환을 치료하며, 잎은 찧어서 붙이면 새살을 돋아나게 하고 상처를 아물게 한다고 알려져 있다. 피부노화를 설명하는 이론은 여러 가지가 있으나, 그 중에도 체내외의 여러 가지 원인으로 발생되는 자유라디컬 에 의하여 피부가 노화된다는 자유라디칼 이론이 가장 타당 성 있는 이론으로 받아들여지고 있다[3]. 인체대사과정 중 산 소 일부분은 superoxide $\left(\mathrm{O}_{2}{ }^{-}\right)$, 과산화수소 $\left(\mathrm{H}_{2} \mathrm{O}_{2}\right)$, hydroxy

*Corresponding author

Tel : +82-53-819-1429, Fax: +82-53-819-1429

E-mail : anbj@dhu.ac.kr radical $\left(\mathrm{HO}^{-}\right)$, singlet oxygen $\left({ }^{1} \mathrm{O}_{2}\right)$ 과 같은 활성산소로 변환 되고, DNA, RNA, 단백질, 세포막 및 세포구조에 손상을 입 힌다. 그리고 활성산소 종들의 독성은 암, 조직손상, 노화 등 의 주원인으로 생각되고 있으며, a-tocopherol, $\beta$-carotene, 아스코르브산(ascorbic acid)와 butylated hydroxy anisole (BHA), butylated hydroxy toluene (BHT) 및 nordihydroguaiaretic acid (NDGA)과 같은 지용성 및 수용성 항산 화제 또는 라디컬소거제들로 최소화 될 수 있다[10]. 최근 합 성항산화제가 인체에 여러 암을 유발하는 등, 부작용으로 인 해 천연식물을 이용한 항산화 원료가 그 효과와 제품의 안정 성으로 인하여 날로 각광을 받고 있다. 염증반응은 생체에 이물질이 감염 또는 침입하였거나 물리 화학적 손상을 입었 을 때 이를 방어하기 위한 국소적 현상이지만, 과잉의 생체 방어 반응은 염증 국소 주위에 있는 정상조직을 손상시켜 염 증질환을 일으킨다. 염증반응이 일어나는 과정 중에 많은 양 의 염증유도 사이토카인(proinflammatory cytokines), nitro oxide (NO) 그리고 prostaglandin $\mathrm{E}_{2}\left(\mathrm{PGE}_{2}\right)$, inducible nitric oxide synthase (iNOS)가 생성된다. 일반적인 $\mathrm{NO}$ 는 박테리 아를 죽이거나 종양을 제거하는 중요한 역할을 하지만 병리 적인 원인에 의한 과도한 $\mathrm{NO}$ 형성은 염증을 유발시켜 조직 의 손상, 유전자 변이 및 신경손상을 일으킨다[19]. 현재까지 개발되어 이용되고 있는 일부 합성 염증 억제제는 그 효능과 
부작용이 확실히 검증되지 않았고, 고가라는 문제점이 있다. 건강에 대한 관심도가 급증하면서 피부 트러블을 보완 할 수 있는 천연 항염증 소재에 대한 관심이 증대되고 있으나 아직 다양한 천연소재들이 개발되어있지 않다. 본 연구에서는 찔 레나무뿌리( $R$. multiflora root)을 열수, 에탄올, 메탄올 및 아 세톤으로 추출하여 항산화 및 항염증 효과를 확인하고 또한, 기능성화장품 소재로의 적합 가능성을 확인하였다.

\section{재료 및 방법}

\section{실험재료 및 시료의 추출}

본 실험에 사용한 찔레나무뿌리는 대구약령시에서 구입하 여 이물질을 제거하고 세척한 후, 음건하여 실험재료로 사용 하였다. 시료의 열수추출물의 경우 시료의 10 배의 증류수를 첨가하여 $85^{\circ} \mathrm{C}$ 에 3 시간 환류냉각 추출하여 상등액과 침전물 을 분리하여 3회 반복 추출하였으며, 에탄올, 메탄올 및 아세 톤 추출물 시료 중량의 10 배 양을 가하여 실온에서 24 시간 침지하여 상등액과 침전물을 분리하여 동일한 방법으로 3회 반복 추출 하여 추출물을 여과, 농축 및 동결건조 후 $4^{\circ} \mathrm{C}$ 냉장 실에 보관하여 본 실험의 시료로 사용하였다.

\section{실험 시약}

항산화능 측정 실험에 사용된 시약인 1-1-diphenyl-2-picrylhydrazyl (DPPH), xanthine, xanthine oxidase, pyrogallol, nitro blue tetrazolium (NBT), 2,2'-azino-bis (3-ethylbenzothiazoline-6-sulfonic acid) diammonium salt, potassium persulfate, hyaluronidase (HAase), hyaluronic acid, p-dimethylaminobenzaldehyde (DMAB), sodium nitrite 및 griess reagent 등은 Sigma Chemical Co. Ltd. (St. Louis, MO, USA)에서 구입 하여 사용하였다. 세포 독성 측정에 사용된 세포주는 mouse대 식세포인 Raw 264.7 cell을 Korean Cell Line Bank (KCLB)에 서 구입하여 사용하였다. 세포독성 측정시약 3-[4,5-dimethylthiazol-2-yl]-2,5-diphenyl-tetrazoliumbromide (MTT)는 Sigma Chemical Co.에서 구입하여 사용하였다.

\section{총 폴리페놀 함량 측정}

폴리페놀 함량은 Folin과 Denis [18]에 준하여 정량 하였다. 10 배 희석한 시료용액 $3 \mathrm{ml}$ 에 $1 \mathrm{~N}$ Folin-Ciocalteu phenol reagent 시약 $1 \mathrm{ml}$ 를 가하고, $1 \mathrm{~N} \mathrm{HCl} 0.2 \mathrm{ml}$ 로 반응정지 후 포화 $\mathrm{Na}_{2} \mathrm{CO}_{3}$ 용액 $1 \mathrm{ml}$ 를 가하여 혼합한 후 1 시간 실온에서 방치하고, $640 \mathrm{~nm}$ 에서 흡광도를 측정한 후, 표준물질인 tannic acid로 미리 작성한 표준곡선의 흡광도 값과 비교하여 폴리페 놀 함량을 산출하였다.

\section{전자공여능 측정}

EDA (electron donating abilities)은 Blois의 방법[4]을 따라
측정하였다. 각 시료용액 $2 \mathrm{ml}$ 에 $0.2 \mathrm{mM}$ 의 DPPH $1 \mathrm{ml}$ 을 넣고 교반한 후 30 분간 방치한 다음 $517 \mathrm{~nm}$ 에서 흡광도를 측정하였 다. 전자공여능은 시료용액의 첨가군과 무첨가군의 흡광도 감 소율로 나타내었다.

$$
\text { 전자공여능 }(\%)=\left(1-\frac{\text { 시료첨가군의 흡광도 }}{\text { 무첨가군의 흡광도 }}\right) \times 100
$$

\section{ABTS radical cation decolorization 측정}

ABTS radical을 이용한 항산화력 측정은 Pellegrin등의 방 법[16]에 의하여 측정하였다. $7 \mathrm{mM}$ 의 2,2-azino-bis (3-ethylbenzthiazoline- 6-sulfonic acid)와 $2.4 \mathrm{mM}$ 의 potassium persulfate를 최종 농도로 혼합하여 실온인 암소에서 24시간 동안 방치하여 $\mathrm{ABTS}^{+}$- 을 형성시킨 후 phosphate buffered saline 로 희석하여 $\mathrm{ABTS}^{+} \cdot 100 \mu \mathrm{ll}$ 에 시료100 $\mathrm{\mu l}$ 를 가하여 1 분 동안 방치한 후 $732 \mathrm{~nm}$ 에서 흡광도를 측정하였다.

$$
\text { 소거능 }(\%)=\left(1-\frac{\text { 시료첨가군의 흡광도 }}{\text { 무첨가군의 흡광도 }}\right) \times 100
$$

\section{Superoxide dismutase (SOD) 유사활성 측정}

SOD 유사활성은 Marklund 등의 방법[1974]에 따라 측정하 였다. 각 시료용액 $0.2 \mathrm{ml}$ 에 Tris $\mathrm{HCl}$ 의 완충용액 $(50 \mathrm{mM}$ Tris + $10 \mathrm{mM}$ EDTA, pH 8.5) $2.6 \mathrm{ml}$ 와 $7.2 \mathrm{mM}$ 의 pyrogallol 0.2 $\mathrm{ml}$ 를 가하여 $25^{\circ} \mathrm{C}$ 에서 10 분간 반응시킨 후 $1.0 \mathrm{~N} \mathrm{HCl} 0.1 \mathrm{ml}$ 를 가하여 반응을 정지시키고 반응액 중 산화된 pyrogallol의 양을 $420 \mathrm{~nm}$ 에서 측정하였다. SOD 유사활성은 시료용액의 첨가군과 무첨가군의 흡광도 감소율로 나타내었다.

$$
\mathrm{SOD} \text { 유사활성능 }(\%)=\left(1-\frac{\text { 시료첨가군의 흡광도 }}{\text { 무첨가군의 흡광도 }}\right) \times 100
$$

\section{Superoxide anion radical 소거능 측정}

Superoxide anion radical 소거능은 Fridovich의 방법[9]에 따라 NBT 환원방법으로 측정하였다. 각 시료용액 $0.1 \mathrm{ml}$ 와 $0.1 \mathrm{M}$ potassium phosphate buffer $(\mathrm{pH} 7.5) 0.4 \mathrm{ml}$ 에 xanthine $(0.4 \mathrm{mM})$ 과 $\mathrm{NBT}(0.24 \mathrm{mM})$ 을 녹인 기질액 $1 \mathrm{ml}$ 을 첨가하고 xanthine oxidase $(0.2 \mathrm{U} / \mathrm{ml}) 1 \mathrm{ml}$ 를 가하여 $37^{\circ} \mathrm{C}$ 에서 20 분간 반응시킨 후 $1 \mathrm{~N} \mathrm{HCl} 1 \mathrm{ml}$ 을 가하여 반응을 종료시킨 다음, 반응액 중에 생성된 superoxide anion radical의 양을 $560 \mathrm{~nm}$ 에서 흡광도를 측정하였다.

$$
\text { 저해율 }(\%)=\left(1-\frac{\begin{array}{c}
\text { 시료첨가군의 superoxide anion } \\
\text { radical 생성량 }
\end{array}}{\begin{array}{c}
\text { 무첨가군의 superoxide anion } \\
\text { radical 생성량 }
\end{array}}\right) \times 100
$$

\section{Hyaluronidase 저해능 측정}

HAase 저해 활성 측정은 Reissig 등의 방법[18]에 의하여 sodium-hyaluronic acid (HA)로 부터 형성된 N-acetylglucosamine을 glucoxazoline 유도체로 변형시킨 후 DMAB로 
발색시켜 흡광도를 측정하였다. $0.1 \mathrm{M}$ acetate buffer $(\mathrm{pH}$ 3.5)에 녹인 HAase $(7,900 \mathrm{U} / \mathrm{ml}) 0.05 \mathrm{ml}$ 와 시료용액 $0.1 \mathrm{ml}$ 를 혼합하여 $37^{\circ} \mathrm{C}$ 에서 20 분간 반응시켰다. $12.5 \mathrm{mM} \mathrm{CaCl} 2$ $0.1 \mathrm{ml}$ 를 가하고 혼합 후 다시 20 분간 배양하였다. 기질로서 $0.1 \mathrm{M}$ acetate buffer ( $\mathrm{pH}$ 3.5)에 녹인 $\mathrm{HA}(12 \mathrm{mg} / \mathrm{ml})$ 을 첨 가하여 다시 40 분간 배양하여 $0.4 \mathrm{~N}$ potassiumtetraborate $0.1 \mathrm{ml}$ 및 $0.4 \mathrm{~N} \mathrm{NaOH}$ 용액 $0.1 \mathrm{ml}$ 를 반응 혼합물에 첨가하 여 3 분 동안 수욕 상에서 가열한 후 완전히 냉각시켰다. 냉각 시킨 반응물에 발색제로 $\mathrm{DMAB}$ 시약 $3 \mathrm{ml}$ 를 가하여 $37^{\circ} \mathrm{C}$ 에 서 20 분간 반응시킨 후 $585 \mathrm{~nm}$ 에서 흡광도를 측정하여 저해 활성을 산출하였다.

\section{세포배양}

본 실험에 이용한 각 세포의 배양은 $10 \%$ fetal bovine serum (FBS)과 Dulbeco's modified eagle's medium (DMEM) 배지를 사용하였으며, $37^{\circ} \mathrm{C}, 5 \% \mathrm{CO}_{2}$ incubator에 적응시켜 계 대 배양하였다.

\section{MTT assay에 의한 세포 생존율 측정}

세포독성 측정은 Camichael 등의 방법[6]에 따라 측정하였 다. Raw 264.7 cell를 96 well plate에 $0.6 \sim 8 \times 10^{3}$ cells/well이 되게 $0.18 \mathrm{ml}$ 분주하고 24 시간 동안 세포를 안정시킨 후 각각 의 시료를 농도별로 조제하여 $0.02 \mathrm{ml}$ 첨가한 후 $37^{\circ} \mathrm{C}, 5 \%$ $\mathrm{CO}_{2}$ incubator에서 24시간 배양하였다. 대조군은 시료와 동량 의 증류수를 첨가하여 동일한 조건으로 배양하였다. 여기에 $5 \mathrm{mg} / \mathrm{ml}$ 농도로 제조한 MTT 용액 $0.02 \mathrm{ml}$ 을 첨가하여 4 시간 배양한 후 배양액을 제거하고 각 well당 DMSO:Ethanol (1:1) $0.15 \mathrm{ml}$ 를 가하여 실온에서 30 분간 반응 시킨 뒤 ELISA reader 로 $550 \mathrm{~nm}$ 에서 흡광도를 측정하였다. 세포독성 측정은 시료 용액의 첨가군과 무첨가군의 흡광도 감소율로 나타내었다.

$$
\text { 세포독성 }(\%)=\left(1-\frac{\text { 시료첨가군의 흡광도 }}{\text { 무첨가군의 흡광도 }}\right) \times 100
$$

\section{Nitric oxide 저해능 측정}

$\mathrm{NO}$ 는 반감기가 5 초 4 분 밖에 되지 않는 매우 불안정한 유 리 라디컬이기 때문에 $\mathrm{NO}$ 의 측정은 실제적으로 불가능하다. 따라서 Raw 264.7 cell에서 nitric oxide synthase 을 발현시키 고 생성된 supernatant 에 포함된 $\mathrm{NO}$ 의 양을 nitrite에 대한 nitrate로 환원된 후의 안전한 형태인 griess reagent (Sigma, USA)를 사용하여 측정하였으며, 6 well plate에 $2 \times 10^{6}$ 개의 cell 을 confluence가 $80 \%$ 일 때, $\mathrm{PBS}$ 로 2 번 washing 한 후 무혈청 배지를 사용하여 12 시간 이상 배양시킨 다음 lipopolysacchride (LPS) $10 \mu \mathrm{g} / \mathrm{ml}$ 을 control 군을 뺀 모든 well에 다 넣어서 자극시켰다. 2시간 후에 R. multiflora root 추출물을 농도별로 처리하여 실험하였다. NO 생성량은 24시간 후에 supernatant를 모아 griess regent로 10 분간 반응시킨 후에 형성
된 분홍색 생성물을 ELISA reader를 이용하여 $540 \mathrm{~nm}$ 에서 흡광도로 측정하였다.

\section{Western blot을 통한 iNOS 단백질의 발현 측정}

Raw 246.7 cell를 $60 \mathrm{~mm}$ tissue culture dish에 $2 \times 10^{6}$ cell/well이 되도록 분주하여 24 시간 동안 $37^{\circ} \mathrm{C}, 5 \% \mathrm{CO}_{2}$ incubater에 배양하고 confluence가 $80 \%$ 일 때 DMEM배지를 무혈청 배지로 교환한 다음 LPS $(10 \mathrm{\mu g} / \mathrm{ml})$ 를 처리하여 2시간 동안 배양 후 R. multiflora root 추출물을 농도별로 처리하여 24시간 배양하였다. 상층액를 제거하고 $\mathrm{PBS}$ 로 2회 세척하였 다. Lysis buffer를 첨가하여 cell을 용해시켜 $12,000 \mathrm{rpm}$ 에서 20 분 원심분리하여 얻은 protein은 bovine serum albumin (BSA)을 표준물질로 하여 Bradford assay로 정량 하였으며, $10 \%$ SDS-polyacrylamide gel을 이용하여 $120 \mathrm{~V}$ 에서 1 시간 전 기영동한 후, polyvinylidenedi-fluoride (PVDF) 을 사용하여 $30 \sim 40 \mathrm{~V}$ 에서 2시간 이상 transfer 하였다. Transfer가 끝나면 ponceau S에 담근 후 band를 확인하고 TBST로 2회 washing, $5 \%$ skim milk로 overnight 시켜 background는 제거시켰다. 3 회 washing 후 1 차 antibody $(1: 1,000)$ 를 1 시간 동안 붙인 다 음 2차 antibody $(1: 1,000)$ 를 붙이고 ECL kit (Amersham Pharmacia, England)을 이용하여 film에 옮겨 측정하였다. Band density는 gel doc (Bio-rad, America)로 확인하였다.

\section{결과 및 고찰}

\section{시료의 추출 및 수율}

찔레나무 뿌리의 수율은 Table 1과 같이 열수, 에탄올, 메탄 올, 아세톤 추출물의 수율이 각 $17.75 \%, 14.13 \%, 15.74 \%$, $17.82 \%$ 로 열수와 아세톤 추출물의 수율이 더 높은 것을 확인 할 수 있었다.

\section{찔레나무 뿌리의 총 폴리페놀 함량 측정결과}

대부분 식물들의 항산화능 화합물은 주로 polyphenol 물질 들이며 천연 항산화제로서의 기능이 잘 알려져 있다[17].

폴리페놀계 물질들은 식물체에 특수한 색깔을 부여하고 산

Table 1. Yields of Rosa multiflora root extracts

\begin{tabular}{cc}
\hline Samples & Yeild (\%) \\
\hline${ }^{1}$ RMR-W & 17.75 \\
${ }^{2}$ RMR-E & 14.13 \\
${ }^{3}$ RMR-M & 15.74 \\
${ }^{4}$ RMR-A & 17.82 \\
\hline
\end{tabular}

${ }^{1}$ RMR-W: $R$. multiflora root extracted with water ${ }^{2}$ RMR-E: $R$. multiflora root extracted with ethanol ${ }^{3}$ RMR-M: $R$. multiflora root extracted with methanol ${ }^{4}$ RMR-A: $R$. multiflora root extracted with acetone Result are means \pm SD of triplicate data. 
화환원반응에서 기질로 작용하며, 한 분자 내에 2 개 이상의 phenolic hydroxyl $(\mathrm{OH})$ 기를 가진 방향족 화합물들을 가리키 며 항산화, 항암 등의 다양한 생리활성을 가진다[14]. 찔레나무 뿌리에 존재하는 총 폴리페놀 함량의 경우 Table 2 와 같이 열 수, 에탄올, 메탄올, 아세톤 추출물에서 각각 $57.48 \pm 0.88 \mathrm{mg} / \mathrm{g}$, $61.2 \pm 0.04 \mathrm{mg} / \mathrm{g}, 61.5 \pm 0.01 \mathrm{mg} / \mathrm{g}, 67.05 \pm 0.56 \mathrm{mg} / \mathrm{g}$ 으로 아세 톤 추출물에서 폴리페놀 함량이 제일 높게 나타났다.

\section{전자공여능확인}

찔레나무뿌리의 전자공여능 측정결과 Fig. 1 과 같이 찔레나 무뿌리 열수 추출물의 경우 $50 \mu \mathrm{g} / \mathrm{ml}$ 에서 $40 \%$ 이상의 효능을 보였고, 에탄올, 메탄올 및 아세톤 추출물의 경우 $100 \mu \mathrm{g} / \mathrm{ml}$ 에 서 $80 \%$ 이상의 효과를 나타내어 같은 농도의 양성대조군 vit-C보다 우수한 radical 소거능을 나타내었다. 이는 Jung [13] 등 의 괴화, 녹차, 작약, 생강 메탄올 추출물의 전자공여능이

Table 2. The contents of total polyphenol of from $R$. multiflora root extracts

\begin{tabular}{cc}
\hline Samples & polyphenol contents $(\mathrm{mg} / \mathrm{g})$ \\
\hline${ }^{1}$ RMR-W & $57.48 \pm 0.88$ \\
${ }^{2}$ RMR-E & $61.23 \pm 0.04$ \\
${ }^{3}$ RMR-M & $61.59 \pm 0.01$ \\
${ }^{4}$ RMR-A & $67.05 \pm 0.56$ \\
\hline
\end{tabular}

${ }^{1} \mathrm{RMR}-\mathrm{W}: R$. multiflora root extracted with water ${ }^{2}$ RMR-E: $R$. multiflora root extracted with ethanol ${ }^{3}$ RMR-M: $R$. multiflora root extracted with methanol ${ }^{4}$ RMR-A: $R$. multiflora root extracted with acetone Result are means \pm SD of triplicate data.

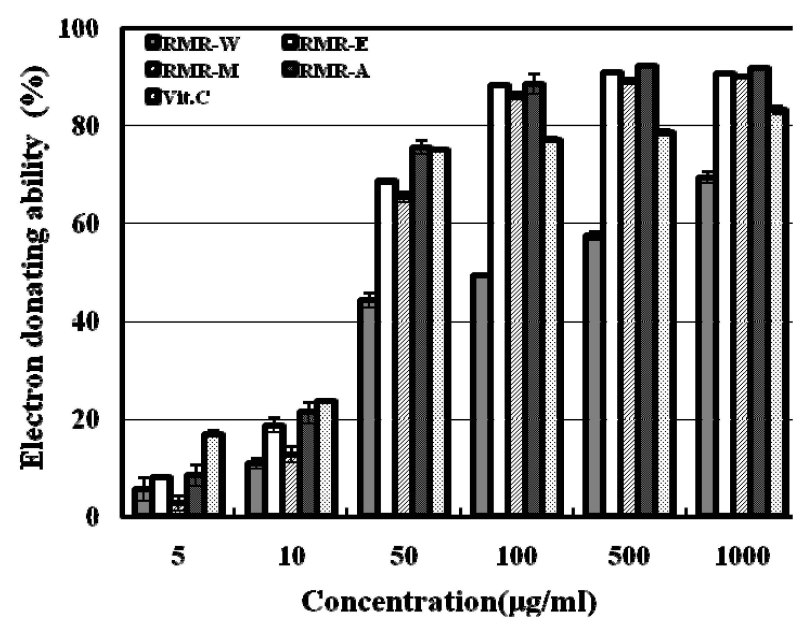

Fig. 1. Electron donating ability of $R$. multiflora root extracts. RMR-W: $R$. multiflora root extracted with water, RMR-E: $R$. multiffora root extracted with ethanol, RMR-M: $R$. multiflora root extracted with methanol, RMR-A: $R$. multiflora root extracted with acetone, Vit. C: ascorbic acid, Result are means \pm S.D. of triplicate data.
$1,000 \mu \mathrm{g} / \mathrm{ml}$ 농도에서 각 $76.9 \%, 64.6 \%, 57.1 \%, 48.3 \%$ 의 활성 을 나타낸 결과와 비교하면 찔레나무 뿌리의 라디컬 소거능이 더 우수함을 확인 할 수 있었다.

ABTS radical cation decolorization 측정결과

찔레나무뿌리의 ABTS radical cation 소거활성 결과 Fig. 2에 나타낸 바와 같이, 찔레나무뿌리 메탄올 및 아세톤 추출물 의 경우 $50 \mu \mathrm{g} / \mathrm{ml}$ 에서 양성대조군 vit-C와 유사한 $80 \%$ 이상의 radical 소거능을 확인하였으며, 열수 및 에탄올 추출물에서는 $75 \%$ 이상의 radical 소거능을 나타내었다. 또한, $\mathrm{DPPH}$ 법에 의한 전자공여능에서 찔레나무뿌리 아세톤 추출물 $50 \mu \mathrm{g} / \mathrm{ml}$ 농도에서 $78 \%$ 정도의 항산화력을 보인 반면 $\mathrm{ABTS}$ 양이온 소 거능에서는 $90 \%$ 로 더 우수한 효능을 확인하였다. 이것은 radi$\mathrm{cal}$ 소거능이라는 점에서는 같으나 $\mathrm{DPPH}$ 경우는 free radical 이지만 ABTS는 cation radical이라는 점에서, 또는 페놀성 물 질의 종류가 다름에 따라 두 기질에 결합하는 정도가 다르고, radical을 제거하는 기작이 다르다는 점에서 활성이 더 높게 나타난 것으로 판단된다.

\section{Superoxide dismutase (SOD) 유사활성 측정결과}

피부 노화방지와 밀접한 관련이 있는 $\mathrm{SOD}$ 유사활성을 측 정한 결과 Fig. 3와 같이 찔레나무뿌리 열수, 에탄올, 메탄올, 아세톤 추출물 $1,000 \mu \mathrm{g} / \mathrm{ml}$ 에서 모두 $20 \%$ 이상의 효능을 확인 하였다. 이는 An 등[2]가 보고한 산사자 열수 추출물과 에탄올 추출물이 $12 \%$ 의 SOD 유사활성능을 나타낸다는 연구결과와 비교하면 찔레나무뿌리 추출물이 더 우수한 SOD 유사활성능 이 있음을 확인할 수 있다.

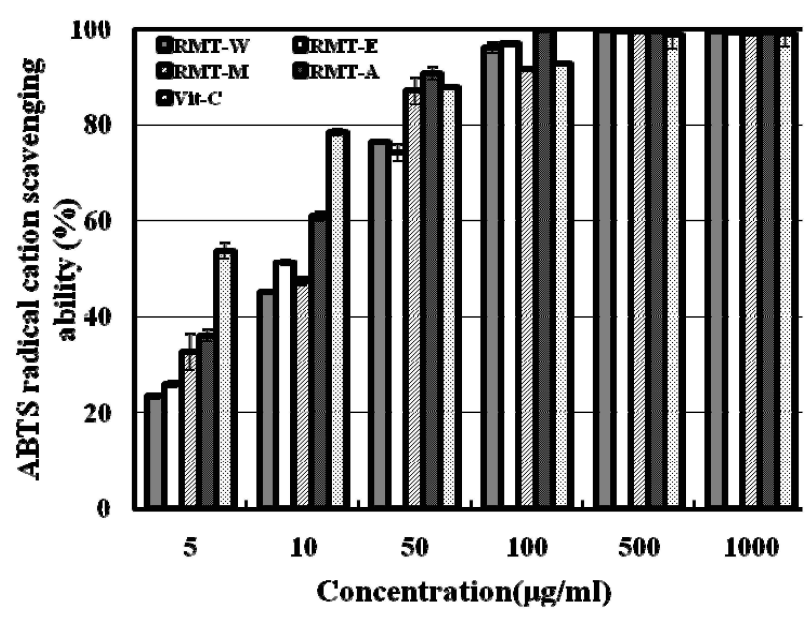

Fig. 2. ABTS radical scavenging ability of $R$. multiflora root extracts. RMR-W: $R$. multiflora root extracted with water, RMR-E: $R$. multiflora root extracted with ethanol, RMR-M: $R$. multiflora root extracted with methanol, RMR-A: $R$. multiflora root extracted with acetone, Vit. C: ascorbic acid. Result are means \pm S.D. of triplicate data. 


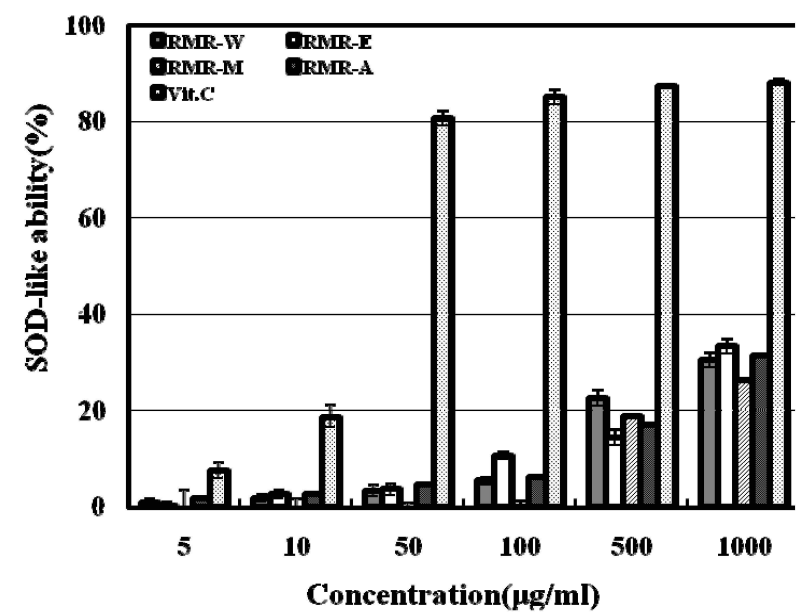

Fig. 3. SOD-like ability of $R$. multiflora root extracts. RMR-W: $R$. multiflora root extracted with water, RMR-E: $R$. multiflora root extracted with ethanol, RMR-M: $R$. multiflora root extracted with methanol, RMR-A: $R$. multiflora root extracted with acetone, Vit. C: ascorbic acid, Result are means \pm S.D. of triplicate data.

\section{Superoxide anion radical 소거능 확인}

Superoxide anion radical 소거능 측정은 xanthine oxidase 가 xanthine을 기질로 하여 uric acid를 생성하는 과정에 생성 되는 superoxide anion radical을 찔레나무뿌리 추출물과 반 응시켜 nitro blue tetrazolium로 superoxide anion radical 소 거능을 확인하는 방법이다[1,15]. Xanthine oxidase에 의해 생 성되는 superoxide anion radical의 생성저해 효과는 Fig. 4에 나타내었다. 찔레나무뿌리 열수, 메탄 및 아세톤 추출물

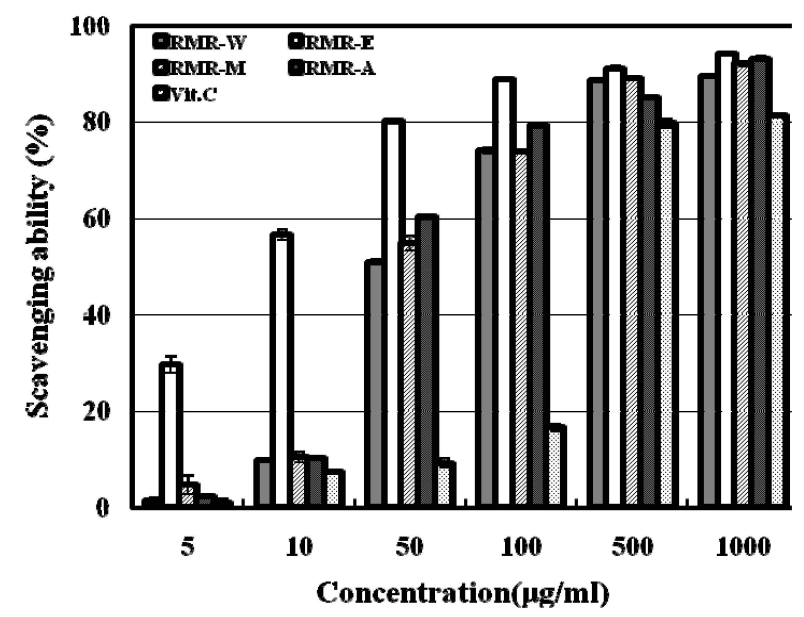

Fig. 4. Superoxide anion radical scavenging ability of $R$. multiflora root extracts. RMR-W: $R$. multiflora root extracted with water, RMR-E: $R$. multiflora root extracted with ethanol, RMR-M: $R$. multiflora root extracted with methanol, RMR-A: $R$. multiflora root extracted with acetone, Vit. C: ascorbic acid, Result are means \pm S.D. of triplicate data.
$50 \mu \mathrm{g} / \mathrm{ml}$ 에서 $50 \%$ 이상의 효능을 보였으며, 에탄올 추출물은 같은 농도에서 양성 대조군인 vit-C보다 우수한 $80 \%$ 이상의 높은 효과를 보였다. 이는 Jeong [11]이 보고한 프로폴리스에 서 분리한 플라보노이드 화합물 quercetin $8 \mu \mathrm{mol}$ 에서 $50 \%$ 이상의 소거활성을 보임과 유사한 superoxide anion radical 소거능을 확인할 수 있었다.

\section{Hyaluronidase 저해능 확인}

본 실험에 사용한 HAase는 hyaluronic의 glucuronic acid 와 N-acetyl-glucosamine의 $\beta(1 \rightarrow 4)$ 결합을 가수분해하는 것 으로 알려져 있다. 이는 결국 고분자 $\mathrm{HA}$ 의 분해 효소인 HAase 의 저해에 의해 $\mathrm{HA}$ 의 고분자 형태를 유지하게 함으로 서 항염증 효과를 기대할 수 있다. 찔레나무뿌리의 HAase 저 해능을 측정한 결과 Fig. 5와 같이 나타났다. 찔레나무뿌리 에 탄올, 메탄올, 아세톤 추출물 $500 \mu \mathrm{g} / \mathrm{ml}$ 에서 $60 \%$ 이상의 높은 HAase 저해 효과를 확인 할 수 있었으며, 양성대조군인 vit-C 가 같은농도에서 $20 \%$ 미만의 효능을 보인 것과 Choi 등[7]의 오가피, 황기 및 두충 에탄올추출물의 HAase 저해능 측정 결 과 $1,000 \mu \mathrm{g} / \mathrm{ml}$ 에서 $60 \%, 61 \%, 63 \%$ 의 저해능을 보인것을 비 교할 때 찔레나무 뿌리의 HAase 효능 효과가 저농도에서 더 우수함을 확인할 수 있다.

\section{MTT assay에 의한 세포 생존율}

찔레나무뿌리 추출물의 세포독성 또는 변성으로 인한 cell population의 저하에 기인하는 결과인지 적용실험 대한 활성 또는 저해능에 대한 정확한 결과 값 인지를 확인하기 위한 과정으로 찔레나무뿌리 추출물에 의한 macrophage cell의 독

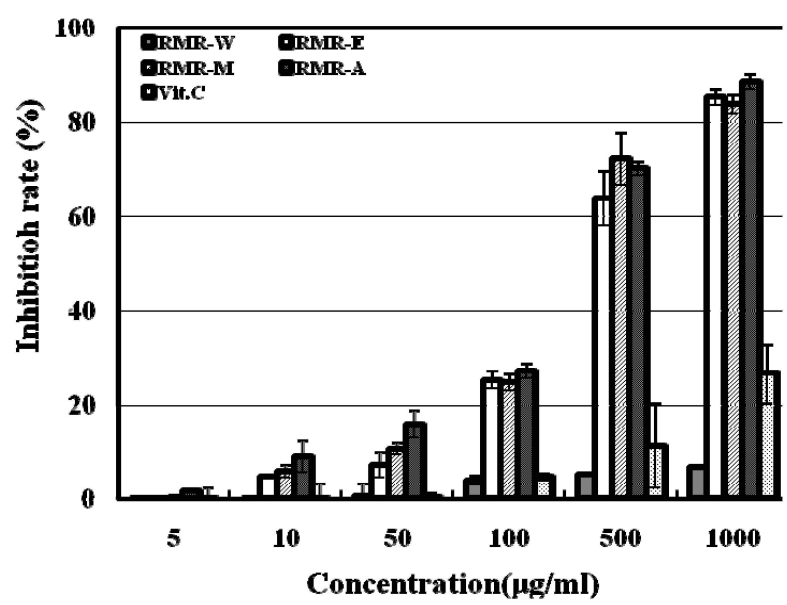

Fig. 5. Inhibition rate of $R$ multiflora root extracts on hyaluronidase. RMR-W: $R$. multiflora root extracted with water, RMR-E: $R$. multiflora root extracted with ethanol, RMR-M: R. multiflora root extracted with methanol, RMR-A: $R$. multiflora root extracted with acetone, Vit. C: ascorbic acid, Result are means \pm S.D. of triplicate data. 
성을 MTT assay에 의해 확인한 결과, Fig. 6와 같이 나타내었 다. 찔레나무뿌리 열수, 에탄올, 메탄올, 아세톤추출물 1,000 $\mu \mathrm{g} / \mathrm{ml}$ 을 첨가한 군에서 각 $52.7 \%, 42.0 \%, 52.1 \%, 58.9 \%$ 의 세포 독성을 보임으로서 세포독성이 없는 $100 \mu \mathrm{g} / \mathrm{ml}$ 이하의 농도 로 실험에 적용하였다.

\section{Nitric oxide 저해능 확인}

$\mathrm{NO}$ 의 형성은 박테리아를 죽이거나 종양을 제거시키는 중 요한 역할을 하지만 과도한 $\mathrm{NO}$ 의 형성은 염증을 유발시키게 되며, 조직의 손상, 유전자 변이 및 신경손상 등을 유발한다 [19]. NO 생성에 대한 찔레나무뿌리 추출물의 효능을 griess 시약을 이용하여 세포배양액 중에 존재하는 $\mathrm{NO}^{2-}$ 의 형태로 측정하였다. LPS를 처리하지 않은 control군에서는 $20 \%$ 미만 의 $\mathrm{NO}$ 가 생성 되었고, LPS를 처리한 군에서는 에탄올 추출물 이 가장 높은 $40 \%$ 의 $\mathrm{NO}$ 생성 억제능을 확인할 수 있었다. 열수, 메탄올, 아세톤 추출물에서도 농도 의존적으로 $\mathrm{NO}$ 생성 이 억제되었으며, 각 추출물 $100 \mathrm{\mu g} / \mathrm{ml}$ 의 농도에서 $30 \%$ 이상 의 높은 NO생성 억제효과를 확인하였다. 이는 Byun 등 [5]의 연구에서 현삼 메탄올 추출물의 NO 생성 억제효과를 나타낸 Fig. 7의 결과와 비교해 보면 찔레나무뿌리 추출물의 $\mathrm{NO}$ 생성 억제능과 유사한 결과를 나타내었고 농도 의존적으로 $\mathrm{NO}$ 생 성이 억제됨을 확인하였다.

\section{iNOS 단백질의 발현 측정 결과}

찔레나무뿌리의 iNOS 단백질의 저해 효과를 확인하기 위 해 Raw 246.7 cell에 LPS $(10 \mu \mathrm{g} / \mathrm{ml})$ 을 처리하고 1시간 뒤, 찔레나무뿌리 에탄올추출물을 농도별로 처리 한 후 western

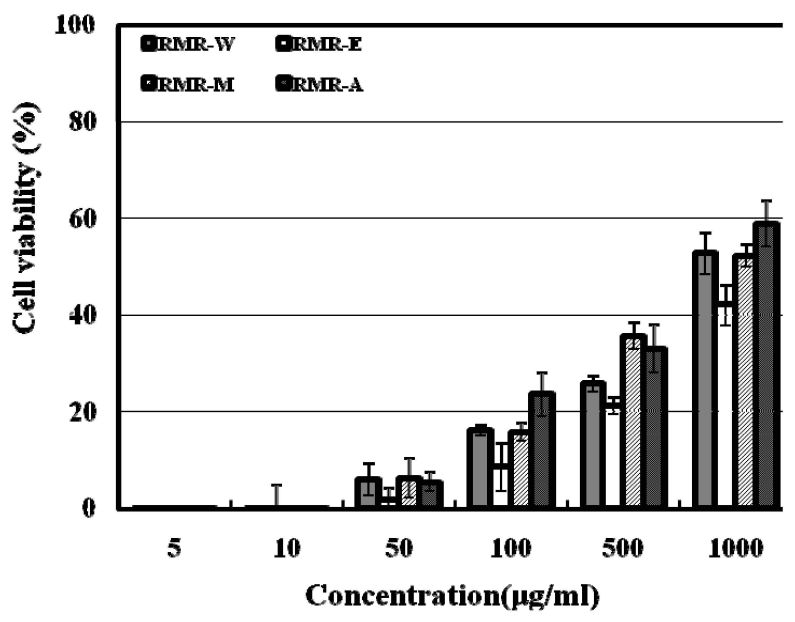

Fig. 6. Cytotoxicity of $R$. multiflora root extracts on macrophage cell (RAW 264.7). RMR-W: $R$. multiflora root extracted with water, RMR-E: $R$. multiflora root extracted with ethanol, RMR-M: $R$. multiflora root extracted with methanol, RMR-A: $R$. multiflora root extracted with acetone, Vit. C: ascorbic acid, Result are means \pm S.D. of triplicate data. blotting으로 확인하였다. Fig. 8와 같이 LPS를 처리하고 찔레 나무뿌리 에탄올추출물을 처리하지 않은 control 군에서는 산 화적 스트레스가 유발되어 염증 반응을 매개하는데 중요한 역할을 하는 것으로 알려진 iNOS protein 발현이 $130 \mathrm{kDa}$ 에서 상당 수준으로 나타났다. 대조적으로 찔레나무뿌리 에탄올추 출물을 농도별로 처리 한 부분에서는 LPS에 의해 증가된

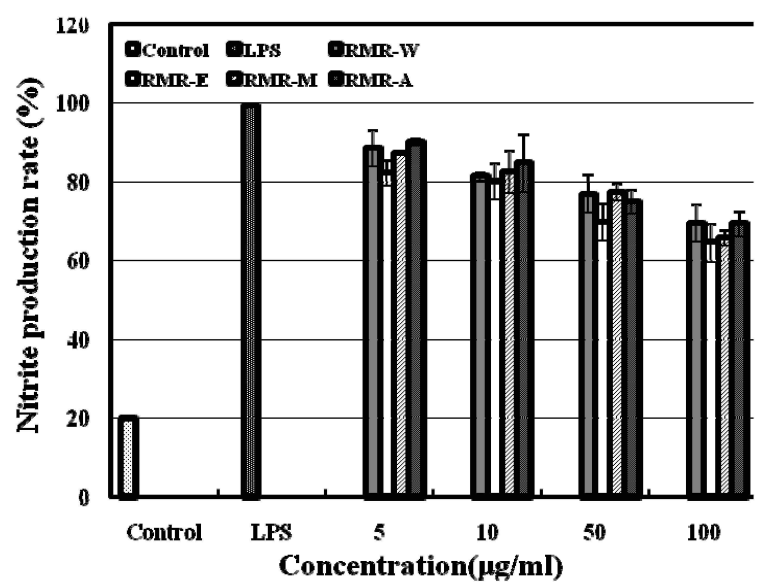

Fig. 7. Effect of $R$. multiflora root extracts on the production of nitric oxide in RAW 264.7 cells. RMR-W: $R$. multiflora root extracted with water, RMR-E: $R$. multiflora root extracted with ethanol, RMR-M: $R$. multiflora root extracted with methanol, RMR-A: $R$. multiflora root extracted with acetone, LPS: lipopoly saccharide, Result are means \pm S.D. of triplicate data.

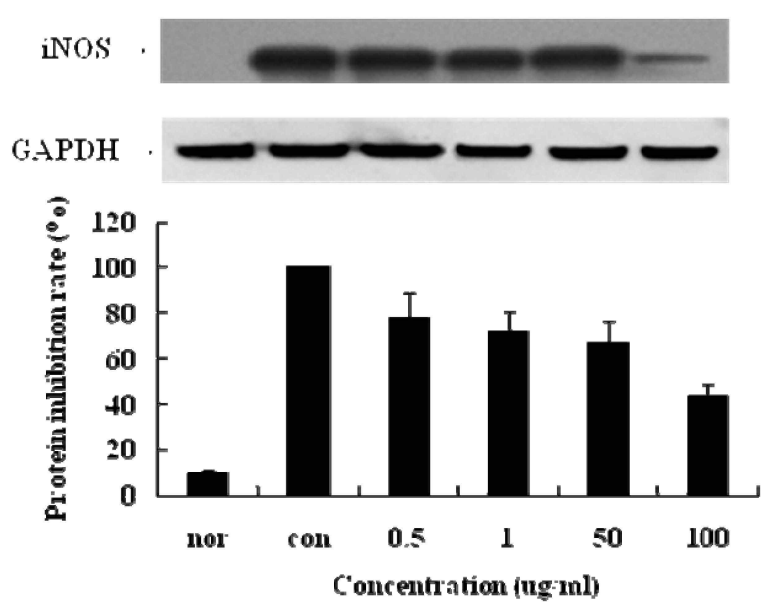

Fig. 8. iNOS protein expression rate of $R$. multiflora root ethanol extracts on macrophage cell (Raw 264.7). After RAW 264.7 cells were treated with different concentrations of R. multiflora root for $1 \mathrm{hr}$ and then LPS $(1 \mu \mathrm{g} / \mathrm{ml})$ was added and the cells were incubated for $24 \mathrm{hr}$. control (Con) values were obtained in the absence of LPS or tested samples. The experiment was repeated three times and similar results were obtained. The values are the mean \pm S.D. of three independent experiments. 
iNOS 단백질 발현을 감소 시켰으며, 특히 에탄올추출물 100 $\mu \mathrm{g} / \mathrm{ml}$ 에서 $40 \%$ 의 iNOS protein 발현 감소효과를 확인할 수 있었다. 따라서 찔레나무뿌리 추출물이 LPS로 유발된 NO 생 성과 $\mathrm{iNOS}$ 발현을 억제함으로 항염증 반응에 관여 한 것으로 사료된다.

\section{References}

1. Amakura, Y., M. Umono, S. Tsuji, H. Ito, T. Hatano, T. Yoshida, and Y. Tonogai. 2002. Constituents and their antioxidative effect in eucalyptus leaf extract used as a natural food additive. Food Chemistry 77, 47-56.

2. An, B. J. and J. T. Lee. 2002. Studies on biologlcal activity from extract of Crataegi fructus. Korean J. Herbology 17, 29-38.

3. Black, H. S. 1987. Potential involvement of free radical reaction in ultraviolet light-mediated cutaneous damage. Photochem Photobiol. 46, 213-221.

4. Blois, M. S. 1958. Antioxidant determination by the use of a stable free radical. Nature 26, 1199-1120.

5. Byun, S. H., C.H. Yang, and S. C. Kim. 2005. Inhibitory effect of Scrophulariae Radix extract on TNF-a, IL-1ß, IL-6 and nitric oxide production in lipopolysaccharide-activated Raw 264.7 cells. Korean J. Herbology 20, 7-16.

6. Carmichael, J., W. G. DeGraff, A. F. Gazdar, J. D. Minna, and J. B. Mitchel. 1987. Evaluation of a tetrazolium based semiautomated colorimetric assay : assessment of chemosensitivity testing. Cancer Res. 47, 936-942.

7. Choi, W. Y., H. J. Chun, J. H. Lee, and S. H. Baek. 2003. Effect of methanol extract from Cornis fructus on melanogenesis. Korean J. Pharmacogn. 31, 70-74.

8. Folin, O. and W. Denis. 1912. On phosphotungastic-phosphomolybdic compounds as color reagents. J. Biol. Chem 12, 239-249.
9. Fridovich, I. 1970. Quantitative aspects of the production of superoxide anion radical by milk xanthin oxidase. J. Bid. Chem 245, 4053-4057.

10. Han, J. T. 2006. Development of functional material using the root of Rosamultiflora. Food Industry Nutrition 11, 59-65.

11. Jeong, I. Y. 2005. Antioxidant activity and radio protection of two flavonoids from propolis. J. Korean Soc. Food Sci. Nutr. 34, 162-166.

12. Jung, B. S. and M. G. Shin. 1990. DoGam HangYak Daesajeon. pp. 648-649, Young Rim Sa, Korea.

13. Jung, S. J., J. H. Lee, H. N. Song, N. S. Seong, S. E. Lee, and N. I. Baek. 2004. Screening for antioxidant of plant medicinal extract. J. Korean Soc. Appl. Biol. Chem 47, 135-140.

14. Kim, J. K. and H. S. Lee. 2000. Tyrosinase inhibitory and radical scavenging activities for the seeds of Coix. Korean J. Food Sci. Technol. 32, 1409-1413.

15. Okamura, H., A. Mimura, Y. Yakou, M. Niwano, and Y. Takahashi. 1993. Antioxidant activity of tannins and flavonoids in Eucalyptus rostrata. Phytochemistry 33, 557-561.

16. Pellegrini, N., A. Proteggente, A. Pannala, M. Yang, R. Re, and C. Rice-Evans. 1999. Antioxidant activity applying an improved ABTS radical cation decolorization assay. Free Radic. Biol. Med 26, 1231-1237.

17. Pratt, D. E., M. T. Huang, S. T. Ho, and C. Y. Lee. 1992. In Phenolic compound in food and their effects on health (II), Antioxidants and Cancer Prevention. pp. 54-71, Washington DC.

18. Reissig, J. L., J. L. Storminger, and L. F. Leloir. 1995. A modified colorimetric method for the estimation of $\mathrm{N}$-acetylamino sugars. J. Biol. Chem. 217, 959-966.

19. Stuehr, D. J., H. J. Cho, N. S. Kwon, M. F. Weise, and C. F. Nathan. 1991. Purification and characterization of the cytokine-induced macrophage nitric oxide synthase: an FADand FMN-containing flavoprotein. Proc. Natl. Acad Sci. 88, 7773-7777.

\section{초록 : 찔레나무뿌리(Rosa multiflora root)의 항산화 및 항염증효과}

박근혜 ${ }^{1} \cdot$ 이진영 ${ }^{2} \cdot$ 김동희 ${ }^{1} \cdot$ 조영제 ${ }^{3} \cdot{\text { 안봉전 }{ }^{1} \star}$

( ${ }^{1}$ 대구한의대학교 화장품약리학과, ${ }^{2}$ 호서대학교 한방화장품과학과, ${ }^{3}$ 경북대학교 식품공학과)

찔레나무뿌리를 열수, 에탄올, 메탄올, 아세톤에서 추출하여 항산화 및 항염증 효능효과를 확인하였다. 그 결과 아세톤추출물에서 가장 많은 $67.05 \pm 0.56 \mathrm{mg} / \mathrm{g}$ 의 폴리페놀 함량을 확인하였으며, SOD 유사활성능을 제외한 $\mathrm{DPPH}, \mathrm{ABTS}$, superoxide anion 라디컬소거능 확인 결과 우수한 항산화 효과를 확인하였다. 찔레나무뿌리 추출 물의 HAase 저해능을 측정한 결과 에탄올, 메탄올, 아세톤 추출물 $500 \mathrm{\mu g} / \mathrm{ml}$ 에서 $60 \%$ 이상의 높은 HAase 저해 효과를 확인할 수 있었다. NO 생성량을 확인한 결과, RAW 264.7 cell에서 LPS에 의해 유도된 NO 생성을 농도 의존적으로 뚜렷하게 감소시키는 것을 확인하였으며, 에탄올 추출물에서 NO 생성억제 효과가 가장 우수한 것을 확인할 수 있었다. 위의 사실에 기초하여 NO 생성저해의 기전을 알아보기 위하여 iNOS의 발현을 분석한 결과, 에탄올추출물 $100 \mathrm{\mu g} / \mathrm{ml}$ 에서 $40 \%$ 의 iNOS protein 발현 감소를 확인하였으며, iNOS의 발현억제가 NO생성억제 와 유사한 경향을 나타냄으로 $\mathrm{NO}$ 생성억제는 $\mathrm{iNOS}$ 의 발현저해를 경유한 것임을 확인할 수 있었다. 이러한 결과 들은 찔레나무뿌리 추출물이 항산화 및 항염증 연구의 기초 자료로 활용될 것으로 예상된다. 또한 추후 산업적 응용도 가능함으로 기능성화장품의 가능성을 제시하고 있다. 